UN IVERSITY OF COPENHAGEN

Dual Income Taxation

Why and How?

Sørensen, Peter Birch

Publication date:

2005

Document version

Publisher's PDF, also known as Version of record

Citation for published version (APA):

Sørensen, P. B. (2005). Dual Income Taxation: Why and How? Economic Policy Research Unit. Department of Economics, University of Copenhagen. http://econpapers.repec.org/paper/kudepruwp/05-10.htm 


\section{EPRU Working Paper Series}

Economic Policy Research Unit

Department of Economics

University of Copenhagen

Studiestræde 6

DK-1455 Copenhagen K

DENMARK

Tel: (+45) 35324411

Fax: (+45) 35324444

Web: http://www.econ.ku.dk/epru/

Dual Income Taxation: Why and How?

Peter Birch Sørensen

2005-10

ISSN 0908-7745

The activities of EPRU are financed by a grant from The National Research Foundation 


\title{
DUAL INCOME TAXATION: WHY AND HOW?
}

\author{
Peter Birch Sørensen \\ Department of Economics, University of Copenhagen, \\ EPRU and CESifo
}

\begin{abstract}
The dual income tax combines a progressive tax schedule for labour income with a low flat tax rate on capital income and corporate income. This paper restates the case for the dual income tax and discusses alternative methods of taxing business income under such a tax system, paying special attention to the taxation of income from closely held corporations. It is argued that the imputed normal return to shares in unlisted companies should be taxed as capital income, while abovenormal returns should be subject to labour income tax. The paper demonstrates that such a tax scheme can be designed to be neutral towards the firm's investment and financing decisions and towards the decisions of shareholders to realize their shares.
\end{abstract}

Keywords: dual income tax, tax neutrality, taxation of business income, shareholder income tax JEL code: H24, H25

Address for correspondence:

Peter Birch Sørensen

Department of Economics, University of Copenhagen

Studiestraede 6, 1455 Copenhagen K, Denmark

E-mail: peter.birch.sorensen@econ.ku.dk 


\title{
DUAL INCOME TAXATION: WHY AND HOW?
}

\author{
Peter Birch Sørensen \\ Institute of Economics, University of Copenhagen, EPRU and CESifo
}

\section{DUAL INCOME TAXATION: A TAX SYSTEM WHOSE TIME HAS COME?}

Recent years have witnessed a growing international interest in the dual income tax, pioneered by the Nordic countries in the early 1990s (see Sørensen, 1994, and Cnossen, 2000). Several countries outside the Nordic region have now introduced elements of dual income taxation (see Eggert and Genser, 2005). Most recently Sinn (2003, Ch. 6) and the German Sachverständigenrat have proposed a dual income tax for Germany (Spengel and Wiegard, 2004), and Keuschnigg and Dietz (2005) have developed an ambitious dual income tax proposal for Switzerland.

The dual income tax combines a low flat tax rate on capital income with a progressive tax on labour income. In the pure version of the system the tax rate on capital income is aligned with the corporate tax rate and with the tax rate on labour income in the first bracket. Labour income (and other forms of non-capital income such as public transfers) above a certain threshold is then subject to a surtax which may contain more than one bracket, depending on the degree of progressivity desired.

Several arguments can be made in favour of such a tax system, as will be explained below. However, a consistent dual income tax requires that income from small enterprises be split into a labour income component and a capital income component. Sørensen (1994) identified the difficulty of undertaking such income splitting as the 'Achilles Heel' of the dual income tax. In particular, the Nordic experience has shown that splitting the income from closely held corporations is a considerable administrative challenge.

This paper restates the case for the dual income tax, describes the issues involved in taxing small enterprises under such a tax system and offers a new solution to the problem of splitting the income from closely held corporations. The proposed solution is in many ways similar 
to that presented in Sørensen (2005) and recently adopted in Norway, but the reform suggested here is arguably easier to administer, and in contrast to the new Norwegian tax system it ensures greater flexibility in the choice of tax rate structure.

To convince the reader that it is indeed worthwhile to adopt a dual income tax (DIT), despite the complexities which are the focus of the present paper, the next section restates the arguments in favour of the DIT. Section III then describes how the income from self-employment may be split under the DIT and how the Nordic countries actually implement income splitting for this group of taxpayers. Section III turns to the more difficult issue of splitting the income from closely held corporations and develops a proposal for a new way of doing so. Section IV compares the proposed system of income splitting with actual tax practices in the Nordic countries, including the new Norwegian tax system which will take effect from 2006. Section V finally summarizes the main conclusions.

\section{DUAL INCOME TAXATION WITHOUT APOLOGY}

\section{II.1. The theoretical case for the DIT}

Conventional tax theory recognizes only two 'grand designs' for a personal tax based on ability to pay: the Schanz-Haig-Simons comprehensive income tax and the Fisher-Kaldor-Meade expenditure tax. As is well-known, the expenditure tax effectively leaves the normal return to capital free of tax, whereas the comprehensive income tax imposes the same marginal tax rate on capital income as on other income. The DIT may be seen as a compromise between a comprehensive income tax and an expenditure tax, since it taxes capital income at a lower marginal tax rate than other income (for taxpayers above the first tax bracket). This section discusses whether there is a theoretical rationale for taxing capital income at a lower (but still positive) marginal rate than labour income, and whether it makes theoretical sense to combine a flat tax on capital income with a progressive rate schedule for labour income.

A natural starting point for the discussion is the classical result of Corlett and Hague (1953) that a commodity tax system which minimizes deadweight loss will impose heavier taxes on goods that are more complementary to (less substitutable for) leisure, since this will minimize taxinduced substitution towards leisure. A capital income tax is effectively a commodity tax on future consumption, so in an intertemporal context the Corlett-Hague result implies that we should tax 
(subsidize) capital income if future consumption is more (less) complementary to leisure than present consumption. Unfortunately there is very little hard evidence indicating whether this is the case.

Given this uncertainty, it seems most appropriate to assume that - as a first approximation - current and future consumption are equally substitutable for leisure, i.e., that preferences are separable in consumption and leisure (as long as we are focusing on broad aggregates such as 'present consumption' and 'future consumption'). We may then apply the powerful result of Atkinson and Stiglitz (1976) that when preferences are separable in consumption and leisure, a government concerned about equity as well as efficiency will not want to differentiate taxes across commodities, provided it can use a labour income tax to achieve its distributional goals. In an intertemporal setting the government will thus abstain from taxing capital income even if the rich tend to earn more capital income than the poor, since the source of the unequal distribution of capital income is an unequal wage distribution (stemming from differences in ability) which can be corrected via a progressive labour income tax. ${ }^{1}$ The intuition for the Atkinson-Stiglitz result is clear: there is no second-best efficiency case for distorting the choice between present and future consumption when these two goods are equally substitutable for leisure; nor is there any equity case for imposing a tax on future consumption, since a wage income tax is a better targeted instrument for redistributing income in a world where innate differences in labour productivity is (assumed to be) the only source of inequality.

The Atkinson-Stiglitz analysis was static and did not allow for the fact that saving for future consumption induces capital accumulation which in turn affects pre-tax factor incomes. However, subsequent research has shown that, provided the government has other instruments (such as debt policy or public investment) to steer the capital stock towards its socially optimal level, a zero steady-state capital income tax rate remains optimal in explicitly dynamic models with capital accumulation, whether these models are of the overlapping-generations type or of the Ramsey-type with infinitely lived consumers (see, e.g., Ordover and Phelps (1979), Judd (1985), and Chamley $(1986))^{2}$

\footnotetext{
${ }^{1}$ This Atkinson-Stiglitz argument abstracts from inherited wealth. But whether inherited wealth calls for a positive capital income tax is not clear if the bequest motive is altruistic.

2 Indeed, in the Ramsey infinite horizon model it is not even necessary to assume separability between consumption and leisure to obtain this result. In the Ramsey model the after-tax steady-state interest rate is closely tied to the consumer's exogenous utility discount rate, so a capital income tax gets fully shifted onto the pre-tax interest rate in the long run. Effectively this means that savings are infinitely elastic in the long run, and clearly it is inoptimal to tax a factor in infinitely elastic supply.
} 
Thus there would seem to be a strong theoretical case for the expenditure tax which exempts the normal return to saving from tax. But the reason why dynamic models of capital accumulation confirm the optimality of a zero capital income tax is that capital accumulation does not affect the distribution of pre-tax wage rates in these models: a higher capital stock simply raises the level of real wages in the same proportion across all skill types. Yet there is strong empirical evidence that skilled labour is more complementary to capital than unskilled labour (see Krusell et alia, 2000), implying that capital accumulation will tend to raise the relative wages of skilled workers. In that case capital accumulation means that a skilled worker has to work fewer hours to earn the same income as an unskilled worker. Ceteris paribus, this makes it more attractive for a skilled worker to mimic an unskilled worker, so the non-mimicking constraint that limits the government's ability to redistribute income from the high-skilled to the low-skilled becomes tighter. To offset this, it becomes optimal for a government concerned about equity to dampen saving and capital accumulation through a positive capital income tax, as shown by Salanié (2003, p. 143).

This result does not assume any market imperfections, relying only on plausible assumptions regarding technology combined with a policy preference for redistribution. But if one realistically allows for the existence of credit constraints, there is also a pure efficiency case for a positive capital income tax, as Chamley (2001) has argued. In the presence of credit constraints, consumers will engage in precautionary saving to hedge against future rainy days, and consumption at any given date will be positively correlated with accumulated precautionary saving. Chamley (op.cit.) shows that capital taxation will then help to redistribute income from high consumption states to low consumption states, thereby performing an insurance function which (by the assumptions of the model) the market cannot provide.

To sum up, in a closed economy context a case for a positive capital income tax rate can be made both on equity grounds and on efficiency grounds, but there are no good theoretical reasons to believe that the marginal tax rates on capital income and on labour income should be the same.

Once we turn to the open economy, we must distinguish between source-based taxes on capital (taxes on capital invested in the domestic economy) and residence-based capital income taxes (taxes on capital owned by domestic residents). If there is no international exchange of information enabling domestic tax authorities to monitor foreign source income, all capital income taxes tend to become source-based, even if the personal income tax is nominally based on the residence principle. We are then left with the celebrated result first established by Gordon (1986) 
that it is inoptimal for a small open economy faced with perfect capital mobility to levy a sourcebased capital income tax. A small economy faces an infinitely elastic supply of capital from abroad, so any source-based tax on domestic investment gets fully shifted onto domestic wage earners as capital flees the country. Through this process of capital flight the domestic economy ends up with an inefficiently low capital intensity of production. Taxing domestic wage earners directly through a labour income tax would be a better strategy, since it does not induce an inefficient switch towards less capital-intensive techniques.

Once again it would thus seem that there is a strong case for not taxing capital income when the openness of the economy is accounted for, assuming that international policy coordination to maintain some 'appropriate' level of capital taxation is not a realistic option. However, in practice the adjustment costs associated with investment make physical capital less than perfectly mobile, and even when it comes to financial capital, the strong home-bias in investor portfolios suggests that governments do have some scope for taxing returns to capital. ${ }^{3}$ Thus, while capital mobility combined with the difficulty of taxing foreign source income certainly tends to reduce the optimal tax rate on capital income below the optimal marginal tax rate on less mobile labour, it still seems unlikely that the capital income tax rate should be driven all the way down to zero.

A good theoretical case can thus be made for maintaining a positive capital income tax rate, but keeping it well below the top marginal tax rate on labour income. Is it also possible to justify the combination of a flat tax rate on capital income with a progressive tax schedule for labour income, in line with the DIT? In the model with skilled and unskilled labour set up by Salanié (2003, pp. 126-143), the positive optimal capital income tax rate is indeed flat, i.e. highincome earners should face the same marginal capital income tax rate as low-income earners. ${ }^{4}$ Nielsen and Sørensen (1997) showed that when capital income is subject to a positive flat tax rate, it is optimal to tax labour income at a progressive rate schedule in an economy with endogenous investments in human as well as physical capital. The reason is that under a flat labour income tax, the return to human capital investment effectively goes untaxed, since the opportunity cost of education (foregone wages) gets deducted against the same tax rate as that applied to the income resulting from the human capital investment. Combining a flat labour income tax with a flat tax on capital income thus tends to induce overinvestment in human relative to physical capital. To correct for this distortion, it is efficient to introduce progressive taxation of labour income, since this is a

\footnotetext{
${ }^{3}$ Bovenberg and Gordon (1996) suggest that home bias arises because investors are less well informed about foreign than about domestic investment opportunities.

${ }^{4}$ The assumptions needed to extend this result to a setting with more than two skill-types remain to be explored.
} 
way of taxing the returns to human capital investment in line with the capital income tax imposed on the returns to investment in physical capital.

\section{II.2. Some practical arguments for the DIT}

The DIT countries have given up progressive taxation of capital income as a means of redistributing income, although they have maintained a progressive tax schedule for non-capital income in order to achieve their distributional goals. As we have seen, there are some purely theoretical arguments in favour of such a tax system. In particular, as capital becomes increasingly mobile across borders, there is a growing risk that a high domestic capital income tax rate will induce taxpayers to move their wealth abroad where in practice it is very hard to bring into the domestic tax net. Separating the capital income tax rate from the labour income tax schedule allows policy makers to reduce the former to minimize the risk of capital flight. In addition, a number of practical arguments can be given in favour of the DIT: ${ }^{5}$

Inflation: The personal income tax is typically levied on the full nominal return to capital, including the inflation premium which just compensates for the erosion of the real value of nominal assets. Thus (many forms of) capital income would be overtaxed if they were taxed at the high top marginal rate applying to labour income. Applying a low flat tax rate to capital income is a pragmatic way of dealing with this problem.

Levelling the playing field: Capital income accrues in many forms. Some of these (such as imputed rent on owner-occupied housing) are hard to tax for practical or political reasons. Lowering the tax rate on those types of capital income that can be taxed serves to reduce the distortions that arise when certain types of capital income cannot be included in the tax base. A low tax rate also makes it easier to include realized capital gains in the tax base without discouraging and distorting asset trades too much.

Tax arbitrage: Aligning the corporate with the personal tax rate on capital income and equalizing marginal capital income tax rates across taxpayers eliminates the scope for those tax arbitrage activities that seek to exploit such differences in tax rates.

Double taxation of saving: By taxing the return to saving, a conventional income tax tends to discriminate against those taxpayers who save a relatively large part of their lifetime income in the early stages of their life cycle. Reducing the capital income tax rate alleviates this discrimination.

\footnotetext{
${ }^{5}$ For a more detailed discussion of these arguments, see Sørensen (1994 and 1998).
} 
Taken together, all of these theoretical and practical arguments establish a fairly strong case for the DIT. But the DIT does raise some technical problems of taxing income from small enterprises. The remaining part of the paper will focus on these problems and on possible solutions to them.

\section{TAXATION OF INCOME FROM SELF-EMPLOYMENT UNDER A DUAL INCOME TAX}

This main section discusses the taxation of the owners of sole proprietorships and partnerships under the DIT. For convenience, these individuals will be referred to as the self-employed. ${ }^{6}$

\section{III.1. The problem: Income from self-employment derives from both capital and labor}

The self-employed work in their own business, so part of their business income must be seen as labour income. At the same time, the self-employed have also invested (part of) their wealth in their business, so another part of their income consists of a return to their business assets. This must be seen as income from capital. If all of the business income of the self-employed were taxed as labour income at progressive rates, the capital income of these taxpayers would be overtaxed relative to other forms of capital income. On the other hand, if all income from selfemployment were taxed at the low flat rate applying to capital and corporate income, the selfemployed would escape tax progressivity altogether, even though part of their income stems from their work effort.

To avoid such tax unequal tax treatment, it is necessary to split the income of the selfemployed into a labour income component and a capital income component. Since the working hours and effort of the self-employed cannot be observed by the tax authorities, whereas the stock of business assets can in principle be observed, it is natural (and common practice in DIT countries) to split the income of the self-employed by first imputing a 'normal' rate of return to their business assets, which is categorized as capital income, and then treat the residual business profit as labour income. In DIT countries, the imputed return is set as the interest rate on a standard government bond plus a risk premium which is determined by law.

\footnotetext{
${ }^{6}$ This section draws on Hagen and Sørensen (1998) who discuss the taxation of the self-employed in the Nordic countries in more detail.
} 


\section{III.2. Alternative methods of income-splitting}

The imputed rate of return to business assets may be computed on a 'gross assets' or on a 'net assets' basis. Under the 'gross assets' method, the net financial liabilities of the firm are not deducted from the asset base. The labour income of the entrepreneur is thus calculated by deducting an imputed return to 'gross' business assets (the assets recorded in the firm's balance sheet) from the 'gross' profits of the firm (defined as profits before interest), and taxable net capital income is calculated by deducting interest expenses from the imputed return to the gross assets. By contrast, under the 'net assets' method capital income is determined by imputing a return to the net assets of the firm (business assets minus business debt), and labour income is found by deducting this imputed return from net profits (profits after deduction for interest).

If the imputed rate of return equals the rate of interest paid on business debt, the two methods will be equivalent. This is illustrated by the simplified numerical example in Table 1 which shows that the imputed income from capital and labour is exactly the same under the two methods when the imputed return equals the interest rate (assumed here to be 10 percent).

The equivalence between the two methods of income-splitting breaks down if the imputed rate of return deviates from the interest rate on business debt. If the imputed return exceeds the interest rate, a larger fraction of business income will be categorized as capital income (and a correspondingly lower fraction will be taxed as labour income) under the gross assets method than under the net assets method. The opposite will hold if the imputed return is lower than the interest rate.

Moreover, significant deviations between the imputed return and the interest rate on debt will tend to distort business investment under the gross assets method. For example, suppose the imputed return is $15 \%$ whereas the interest rate is only $10 \%$, and suppose an entrepreneur can earn a pre-tax return of $10 \%$ on an additional business investment of 100 . In the absence of tax he would then just break even if he borrowed to finance the investment. But in the presence of tax he would score a net gain, because the investment would add 15 to his imputed capital income, whereas it would add only 10 to total taxable profits. Hence a larger share of total profit would be taxed at the low capital income tax rate rather than at the high labour income tax rate, thereby reducing the entrepreneur's total tax bill. In contrast, under the net assets method of income splitting, the recorded net assets of the firm would not be affected by an additional debt-financed investment. Nor would the investment affect net profits in the example given (gross profits would 
Table 1. The 'gross assets' versus the 'net assets' method of splitting income from self-employment

\section{Income statement}

\begin{tabular}{|l|r|}
\hline Sales revenue & 500 \\
\hline Business expenses & 200 \\
\hline Profit before interest (gross profit) & 300 \\
\hline Interest on business debt (10\%) & 80 \\
\hline Profit net of interest (net profit) & 220 \\
\hline
\end{tabular}

Balance sheet

\begin{tabular}{|lr|lr|}
\hline \multicolumn{2}{|c|}{ Assets } & \multicolumn{2}{c|}{ Liabilities } \\
\hline Business assets & 1000 & Business debt & 800 \\
\hline & Net worth & 200 \\
\hline & 1000 & & 1000 \\
\hline
\end{tabular}

Income-splitting on a gross assets basis

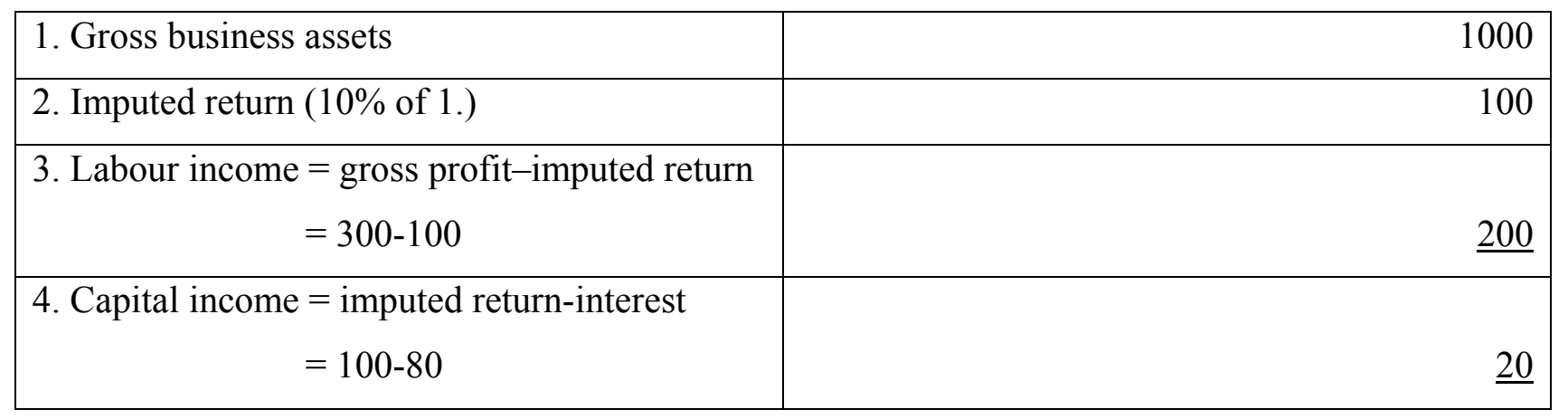

Income-splitting on a net assets basis

\begin{tabular}{|l|r|}
\hline \begin{tabular}{rlr|}
\hline 1. Net business assets $=$ gross assets-debt \\
$=1000-800$
\end{tabular} & 200 \\
\hline 2. Imputed return (10\% of 1.) & 20 \\
\hline $\begin{array}{rlr}\text { 3. Labour income }=\text { net profit-imputed return } \\
=220-20\end{array}$ & $\underline{200}$ \\
\hline 4. Capital income $=$ imputed return & $\underline{20}$ \\
\hline
\end{tabular}


rise by 10 , but so would interest expenses), so this method of income-splitting ensures that the dual income tax remains neutral towards marginal investment decisions.

\section{III.3. Anti-avoidance measures}

The above analysis would seem to imply a preference for the net assets method on tax neutrality grounds, but unfortunately this method also allows greater scope for tax arbitrage. Specifically, the net assets method implies that interest expenses become deductible against the high marginal tax rate on labour income, because they reduce the residual net profit which is taxed as labour income at the margin. This provides a strong incentive for entrepreneurs to record private debt (debt incurred for non-business purposes, say, to finance the purchase of a consumer durable or a house) as business debt in order to benefit from interest deductibility.

To limit the scope for such transactions, the self-declared business income should be adjusted in cases where the declared net assets of the firm become negative, since negative net business assets is a strong indication that private debt has been transferred to the business sphere. Specifically, business income for tax purposes should be raised by the imputed return times the recorded negative net worth of the firm to (roughly) offset the fact that reported business income has been artificially lowered by allocating non-business interest expenses to the firm. To the extent that the tax law allows deduction for non-business interest expenses, the upward adjustment of taxable business income should of course be accompanied by a corresponding downward adjustment of the entrepreneur's non-business capital income (which might well be negative, in which case the entrepreneur would receive a tax credit equal to the capital income tax rate times the negative capital income).

The net assets method may also require a similar adjustment of taxable business income in certain other cases in order to prevent tax arbitrage. For example, if the imputed return is based on net assets at the start of the year, the entrepreneur may reduce his taxable labour income by withdrawing funds from the firm during the year (thereby reducing its recorded net profit by reducing its net interest income) and reinject the funds into the firm before the start of next year in order not to reduce the base for calculating the imputed rate of return. Of course, the interest earned outside the firm on the funds withdrawn from it would attract capital income tax, but at the same time the entrepreneur's imputed labour income would go down, implying a transformation of labour income into capital income. Hence it may be necessary to undertake an upward adjustment of the firm's recorded net interest income (and a corresponding downward adjustment of the 
entrepreneur's 'private' net capital income) in cases where the proprietor withdraws funds from the firm only to reinject them later in the same fiscal year.

Thus the choice between the gross and the net assets method involves a trade-off between the superior neutrality properties of the net assets method and the greater simplicity and lower vulnerability to tax arbitrage offered by the gross assets method.

Another avoidance problem arising under both methods of income-splitting is that entrepreneurs may gain by transferring low-yielding non-business assets (e.g., a piece of real estate or a motor vehicle used for private consumption) from the private sphere to the business sphere. By adding to the recorded stock of business assets an asset with little or zero (taxable) yield, the entrepreneur will have a higher proportion of his business income taxed as capital income, since the base for calculating the imputed return goes up, while total business income stays (almost) unchanged. To prevent such transformation of labour income into capital income, the tax law must include clauses limiting the scope for transferring non-business assets to the business sphere.

\section{III.4. Taxation of the self-employed in the Nordic countries}

The Nordic DIT countries all provide an option for the self-employed to have their income split into a capital income component and a labour income component. Norway uses a variant of the gross assets method, while Finland and Sweden practice variants of the net assets method. Apart from distinguishing between labour and capital income, the Swedish scheme also allows labour income retained in the firm to be taxed at the low corporate income tax rate, postponing imposition of the progressive labor income tax until the time the profits are distributed. Denmark offers the self-employed a choice between the simpler gross assets method and a more complicated net assets method similar to the Swedish scheme.

\section{III.5. Some final observations on income tax design for the self-employed}

In designing tax rules for the self-employed under the DIT, the following considerations should be kept in mind:

1) If the tax rate in the lowest bracket of the labour income tax schedule is aligned with the tax rate on capital income, entrepreneurs whose business income falls within the lowest tax bracket will have no need for income splitting, since they face the same marginal tax rate on capital income and labour income. If the upper threshold for the lowest tax bracket were set fairly high, 
many self-employed would never need to have their income split, allowing a considerable administrative simplification.

2) Income-splitting should be an option but not a requirement for the taxpayer, since it offers an opportunity for entrepreneurs to avoid over-taxation of the capital income component of their business income. If an entrepreneur does not opt for income-splitting, his business income will automatically be taxed as labor income. Income-splitting requires that taxpayers keep proper accounts of their assets and liabilities, so taxpayers wishing to benefit from the low tax rate on capital income will have an incentive to keep proper books rather than relying on simplified accounting. Switching to a dual income tax may therefore help to promote modern business recordkeeping, which may be desirable in itself.

3) In part because it requires fewer anti-avoidance measures, the gross assets method is administratively simpler than the net assets method, for the revenue authorities as well as for taxpayers. If priority is given to simplicity and low compliance costs, this is a strong argument for choosing the gross assets method of income-splitting.

\section{TAXATION OF INCOME FROM CLOSELY HELD COMPANIES}

\section{IV.1. The income shifting problem}

The taxation of small corporations with active owners working in their own business raises a similar issue as the taxation of the self-employed: part of the income from the company must be considered as a return to the capital invested in the firm, and another part is the reward for the work effort and skills of the owner(s). In the absence of special rules for these companies, the dividends and capital gains on shares realized by the owner would be treated as capital income under the DIT (perhaps with some form of relief for the underlying corporation tax), while the management wages paid to the owner(s) would be treated as labour income. If the sum of the corporation tax and the personal tax on dividends and/or capital gains is less than the marginal tax rate on labour income, the owner has an obvious incentive to pay himself dividends or to realize a capital gain on (part of) his shares rather than paying himself a realistic wage. 


\section{IV.2. One possible solution: Treating small companies like proprietorships}

A possible solution to this problem would be to tax the income from small companies accruing to active, controlling shareholders in the same way as income from self-employment. This would imply that a fraction of corporate profits equal to the fraction of shares owned by the 'active' (i.e., working) shareholders be split into an imputed return on corporate assets, which would be taxed as capital income, and a residual profit that would be taxed as labour income. This income splitting would apply regardless of the actual amount of dividends or capital gains realized by the owners, so the owners would be unable to transform labour income into capital income by paying themselves lower wages and instead taking out higher dividends or capital gains. The corporation tax would continue to serve as a withholding tax on corporate profits, but it would be credited against the shareholder's personal tax bill to prevent double taxation of corporate equity income.

The main problem with this scheme is the difficulty of identifying the 'active' controlling shareholders who should be subject to mandatory income-splitting. It would seem natural to require mandatory income-splitting only in cases where 1) the shareholder carries out a certain minimum amount of work in his company, and, in addition, 2) he has a certain mimimum (controlling) ownership share in the firm, possibly in conjunction with his closest relatives. If both these conditions are met, the shareholder may be able to transform management wages or other labour income from the firm into dividends or capital gains to reduce his tax bill. However, one can easily imagine that a controlling shareholder might invite relatives or friends to step in as minority shareholders so that he is no longer subject to the income-splitting rules even if he maintains effective control over the firm's dividend policy. One can even imagine that controlling shareholders might exchange shares in each other's companies to avoid mandatory income-splitting without giving up effective control of their companies. More fundamentally, the dividing line between 'active' and 'passive' shareholders is essentially arbitrary and may lead to unequal tax treatment of shareholders who are for practical purposes in equal positions.

\section{IV.3. An alternative solution: Taxing above-normal returns to shares as labour income}

Because of these difficulties, it seems desirable to avoid having to distinguish between 'active' and 'passive' shareholders. This section describes an alternative scheme which does not require this distinction. In principle, the scheme could be applied to all resident shareholders, but this would require considerable administrative capacity (indeed, it would require a centralized register of all resident shareholders to keep account of all transactions in shares). Moreover, since 
the purpose of the scheme is to address the income shifting problem in smaller companies, it is assumed below that the scheme will only be applied to resident individual (i.e., non-corporate) holders of shares in unlisted companies. The distinction between listed and non-listed companies is simple and administratively easy to implement, and non-listed shares are rarely traded, so the number of share transactions that would need to be monitored would be limited.

The basic principle of the scheme is also simple: The 'normal' return to shares is taxed as capital income, whereas returns above normal are taxed progressively as labour income. The progressive tax on above-normal returns (henceforth termed the surtax) is imposed only when income from the firm is taken out as a dividend or realized as a capital gain on shares. The surtax is levied on the realized income from the shares minus a Rate-of-Return-Allowance, denoted RRA. The realized income is the sum of dividends and any realized net capital gain on the shares in the company. Thus dividends and capital gains are treated symmetrically. If the realized income falls short of the RRA, the unutilized RRA may be carried forward and deducted in a later year.

The RRA is calculated as an imputed rate of return times the basis of the share. The basis for the current year is the sum of the original basis and all unutilized RRAs from previous years. The original basis is determined at the time of the reform as the shareholder's share of the net value of the company's assets at the time of the reform. The original basis is stepped up year by year by any unutilized RRAs. This step-up is necessary to ensure that only capital gains in excess of the normal return are subject to progressive labour income tax.

The imputed rate of return should correspond to a normal after-tax rate of return, since dividends are paid out of taxed profits. Since the corporate tax rate corresponds to the capital income tax rate under a consistent dual income tax, dividends not exceeding the imputed return could be left free of tax at the personal level to avoid double taxation of corporate equity income. ${ }^{7}$ Income from shares exceeding the imputed return should be 'grossed up' by the underlying corporation tax (by dividing the dividend or capital gain by one minus the corporate tax rate), and the progressive surtax should be calculated on this grossed-up basis, with a credit being given for the corporation tax already paid.

The following numerical example illustrates the working of these tax rules. The example assumes that the common tax rate on capital income and corporate income is $20 \%$ whereas the shareholder's marginal tax rate on labour income is $40 \%$. Furthermore, the imputed (after-tax) return on shares is taken to be $8 \%$, corresponding to a pre-tax return of $10 \%$ adjusted for the $20 \%$

\footnotetext{
${ }^{7}$ Companies would be required to keep a taxed profits account to ensure that only 'normal' dividends paid out of taxed profits are exempt from personal tax. See the next section for details.
} 
capital income tax. Finally, it is assumed that the market value of the shares equals the net equity accumulated within the firm.

\section{Year 1}

1. Basis value of shares $\quad 1000$

2. Profit after corporation tax 200

3. Dividend 30

4. Retained profit (2.-3.) 170

5. RRA ( $8 \%$ of 1.$) \quad 80$

6. Unutilized RRA (5.-3.) 50

Year 2

7. Stepped-up basis of share (1.+6.) 1050

8. Profit after corporation tax 230

9. RRA ( $8 \%$ of 7.$) \quad 84$

Scenario 1: Shares are realized at the end of year 2

10. Revenue from sale of shares at the end of year $2(1 .+4 .+8$. $) \quad 1400$

11. Stepped-up basis of share at the start of year $2(=7) \quad$.

12. RRA for year $2(=9$.) 84

13. Taxable capital gain (10.-11.-12.) 266

14. Grossed-up capital gain (13./(1-0.2)) 333

15. Underlying corporation tax $(0.2 \times 14$. $) 67$

16. Surtax $((0.4 \times 14)-$.15 . $) \quad 67$

Scenario 2: All profits are distributed at the end of year 2

17. Dividend at the end of year $2(4 .+8$.) 400

18. Total RRA (6.+9.) 134

19. Taxable dividend (17.-18.) 266

20. Grossed-up dividend (19./(1-0.2)) 333

21. Underlying corporation tax $(0.2 \times 20$. $) 67$

22. Surtax $((0.4 \times 20)-21) \quad$.

In Scenario 1 above the shareholder realizes a pre-tax capital gain equal to 1400-

$1000=400$ at the end of year 2. In Scenario 2 he takes out a similar amount of dividend at the end of year 2. Thus the example shows that the shareholder ends up paying the same amount of tax regardless of whether he receives a given amount of income in the form of dividends or in the form of capital gains. Hence the tax is neutral towards the firm's dividend policy and therefore neutral towards decisions to finance investment by retained earnings or by injection of new equity. 
Another attractive feature of the scheme is that it does not induce shareholders to postpone realization of their shares in order to defer capital gains tax, even though the tax is levied only upon realization. The reason is that the basis of the share is written up every year by any unutilized RRAs. As shown in Box 1, this effectively means that any postponed capital gains tax liability is carried forward with interest, thus eliminating the gain from deferral of realization. ${ }^{8}$

\section{Box 1. Holding period neutrality under a realizations-based capital gains tax with an RRA}

Consider a share with a market value at time $t$ of $M_{t}$ and a basis value of $B_{t}$ at that time. If the shareholder realizes his accumulated capital gain $M_{t}-B_{t}$ at time $t$, and if the tax rate is $\tau$, his tax liability $T_{t}$ will be

$$
T_{t}=\tau\left(M_{t}-B_{t}\right)
$$

If the realization is postponed until time $t+1$, and assuming for simplicity that no dividends are paid in the meantime, the tax liability will be

$$
T_{t+1}=\tau\left[M_{t+1}-(1+r) B_{t}\right]
$$

since the basis of the share will be stepped up by the amount $r B_{t}$ between time $t$ and time $t+1$, where $r$ is the imputed rate of return, and $r B_{t}$ is the unutilized rate-of-return allowance during period $t$. From (1) and (2) we find that

$$
\begin{aligned}
& T_{t+1}-T_{t}=\tau\left[\left(\frac{M_{t+1}-M_{t}}{M_{t}}\right) M_{t}-r B_{t}\right] \\
& =\tau\left[\left(\frac{M_{t+1}-M_{t}}{M_{t}}-r\right) M_{t}+r\left(M_{t}-B_{t}\right)\right] \\
& =\tau\left(\frac{M_{t+1}-M_{t}}{M_{t}}-r\right) M_{t}+r T_{t} \Leftrightarrow \\
& T_{t+1}=(1+r) T_{t}+\tau\left(\frac{M_{t+1}-M_{t}}{M_{t}}-r\right) M_{t}
\end{aligned}
$$

Equation (3) shows that the tax system leaves no advantage from deferring the capital gains tax by postponing the realization from one period to the next. The reason is that the postponed tax liability is carried forward with interest, as reflected in the presence of the term $(1+r) T_{t}$ on the right-hand side of (3).

\footnotetext{
${ }^{8}$ The scheme suggested here is in fact a special case of the generalized cash flow tax described in Auerbach and Bradford (2004). The Auerbach-Bradford scheme ensures holding-period neutrality even though tax is due only when assets are realized.
} 
Sørensen (2005) shows that the tax scheme outlined above will also be neutral towards the firm's real investment decisions and towards the choice between debt and equity finance, since no double taxation of corporate equity income is imposed on equity-financed investment yielding only a normal return. Indeed, the shareholder income tax described here can be shown to be equivalent to a neutral cash flow tax, although the timing of tax payments will differ from that implied by a cash flow tax (see Sørensen, 2005, sec. 4.1). The equivalence stems from the fact that the purchase of a share generates a stream of future RRAs whose present value equals the initial purchase price which would be deductible under a cash flow tax.

\section{IV.4. Implementing the surtax on shareholder income: How would it work in practice?}

To facilitate the administration of the tax, unlisted companies must keep an account for each of their shareholders in which they update the basis value of his shares and his total unutilized RRAs. As a starting point, the initial basis value at the time of reform is determined as the difference between the assets and the debt recorded in the company's tax accounts at that time (perhaps with some adjustments if certain assets are deemed to be inappropriately valued for the purpose of establishing the basis). However, if the taxpayer can document that he purchased his share at a higher price, the basis is set equal to that purchase price.

The RRA for the current year is calculated as the imputed rate of return times the recorded basis value of the share at the start of the year. At the end of the year, the basis value and the accumulated unutilized RRAs are written up by that year's RRA minus the dividend paid out during the year.

Companies would also keep account of their accumulated taxed profits and would record each shareholder's share of these profits and the tax paid on them. The taxation of dividends would then work as follows: If the dividend paid out to a shareholder is less than his total accumulated RRAs (including the RRA for the current year), and if it is also less than his share of the accumulated taxed profits, the company will withhold no tax, and the dividends will be tax exempt at the shareholder level, since the underlying profits have already been taxed at the corporate rate which is assumed to be identical to the capital income tax rate. If the distribution exceeds accumulated taxed profits, the company will withhold corporate income tax on the difference before paying out the dividend, but the remaining dividend will still be exempt at the shareholder level provided it does not exceed the accumulated RRAs. Finally, if the dividend payout does exceed the accumulated RRAs, the company will gross up the 'excess' dividend and 
withhold tax at the top marginal labour income tax rate, grant a credit for the underlying corporation tax, and pay out the remaining dividend to the shareholder. At the same time the company will inform the shareholder of the amount of grossed-up dividend on which tax has been withheld. The shareholder will include the grossed-up dividend in his income tax return and will claim a credit against his personal tax bill for the labour income tax already withheld at the corporate level. In case the credit exceeds the final tax bill, the difference will be paid out to the taxpayer.

This set of dividend tax rules will ensure that i) no dividends will go free of tax if they have not already been taxed at the corporate level; ii) no dividends will be double-taxed, and iii) all dividends above the imputed return will end up being taxed at the appropriate marginal rate, due to the crediting mechanism in the personal income tax.

The taxation of realized gains on shares would work in a similar way. At the start of each year the company informs its shareholders of their stepped-up basis value and their RRA for the coming year as well their allotted share of the company's accumulated taxed profits. If a shareholder sells his share during the year, his taxable capital gain is calculated as the sales price minus the stepped-up basis and minus an appropriate fraction of the RRA for the current year. For example, if the share is sold on July 1, the seller can deduct half of the RRA for the current year, since he has only held the share for half the year. The remaining half of the RRA is allocated to the new shareholder to be set against his taxable dividend for that year. The seller declares his taxable capital gain on his income tax return on which he also records his allotted share of the company's taxed profits. The tax authorities will then gross up the taxable gain and impose labour income tax, while granting a credit for the underlying corporation tax. This credit cannot exceed the actual tax paid on the shareholder's share of the company's taxed profits.

For the new owner of the share, its initial basis value is set equal to the purchase price which must be recorded by the company. This basis is then subsequently written up by any unutilized RRAs accumulated after the acquisition. Of course, taxed company profits are only allocated to the new shareholder from the time he acquires the share.

As shown in Sørensen (2005), a shareholder income tax of the type proposed here will only be fully neutral if it allows full deduction for losses on shares, including 'losses' stemming from unutilized RRAs. For reasons of neutrality, taxpayers should therefore be allowed to offset losses against other income and to carry forward any remaining loss with interest. Under such a symmetric tax, the government will in effect participate as a silent partner in every (unlisted) shareholding, absorbing a fraction of the risk while at the same time taxing a fraction of the return. 
Because of this symmetric risk sharing, one can show that the imputed return does not need to include a risk premium, i.e., it can be set equal to a risk-free interest rate without destroying the neutrality properties of the shareholder income tax (see Sørensen, 2005). However, to the extent that there are limitations on loss offsets, there is a case for including a risk premium in the imputed return.

\section{IV.5. Anti-avoidance rules}

The tax system described here implies that above-normal returns to non-listed shares will be taxed progressively as labour income whereas interest on debt will only be taxed at the low capital income tax rate. This asymmetry might induce companies to distribute their earnings in the form of interest on debt rather than in the form of equity income. Subordinated debt is often a close substitute for equity, and interest on such debt typically includes a substantial risk premium. Hence it may be possible to avoid progressive taxation by paying out above-normal rates of return in the form of interest on loans from shareholders to the company. This may be prevented by an antiavoidance clause stating that whenever the interest rate on a loan from a personal taxpayer to a nonlisted company exceeds the imputed rate of return on shares, the difference will be taxed as labour income.

\section{IV.6. Discrimination between proprietorships and small companies?}

Under the tax system sketched above shareholders are not taxable on their imputed labour income until this income is realized in the form of dividends or capital gains. By contrast, the income splitting system for the self-employed described earlier implies that the imputed labour income of the self-employed will be taxed on a current basis, whether or not the income is retained in the firm. One might think that the possibility for the owners of corporate firms to postpone labour income tax until the time of distribution/realization would imply an unfair tax advantage compared to the tax treatment of the self-employed. However, we will now provide a simplified example to show that in principle this is not the case.

Consider an entrepreneur who invests one unit of capital in his firm at the start of period 1. This capital yields a pre-tax return equal to the pre-tax market interest rate $r$. In addition, the entrepreneur's work effort generates a business income $w$. All of the after-tax business income generated in period 1 is retained in the firm, and at the end of period 2 the entrepreneur sells the firm. If he organizes the firm as a proprietorship, his imputed capital income under the income 
splitting system will be $r$ times the stock of business capital at the start of each period. This imputed income will be taxed at the capital income tax rate $t$, while the remaining business income will be taxed as labour income at the rate $t^{l}$. Denoting the after-tax interest rate by $i \equiv r(1-t)$, we may then sum up the proprietor's situation as follows, assuming that the value of the firm at the end of period 2 equals the value of its accumulated assets at that time:

\section{Scenario 1: The firm is organized as a proprietorship}

\section{Year 1}

1. Initial capital stock: 1

2. Business income before tax: $r+w$

3. Tax bill: $t r+t^{l} w$

4. Retained after-tax business income (2.-3.): $i+w\left(1-t^{l}\right)$

\section{Year 2}

5. Initial capital stock (1.+4.): $1+i+w\left(1-t^{l}\right)$

6. Business income before tax $(r \times(5)+w):. r\left[1+i+w\left(1-t^{l}\right)\right]+w$

7. Tax bill: $\operatorname{tr}\left[1+i+w\left(1-t^{l}\right)\right]+t^{l} w$

8. Retained after-tax business income (6.-7.): $(1+i)\left[i+w\left(1-t^{l}\right)\right]$

9. Revenue from sale of firm $(5 .+8):.(1+i)^{2}+(2+i) w\left(1-t^{l}\right)$

As an alternative, the entrepreneur may organize his firm as a corporation. Under the DIT, the corporate income tax rate equals the capital income tax rate $t$. This is the rate at which the business income is taxed as long as the income is retained in the firm. When the entrepreneur sells his shares in the firm at the end of period 2, the excess of his sales revenue over his rate-of-return allowance is grossed up and taxed at the labour income tax rate $t^{l}$, with a credit being given for the corporation tax already paid. Hence the situation for an entrepreneur choosing the corporate organizational form looks as follows: 


\section{Scenario 2: The firm is organized as a corporation}

\section{Year 1}

10. Initial capital stock $=$ initial basis of shares: 1

11. Business income before tax: $r+w$

12. Corporate income tax bill: $t(r+w)$

13. Retained after-tax business income (11.-12.): $i+w(1-t)$

\section{Year 2}

14. Initial capital stock $(10 .+13):. 1+i+w(1-t)$

15. Basis of shares at the start of the year: $1+i$

16. Business income before tax $(r \times(14)+w):. r[1+i+w(1-t)]+w$

17. Corporate income tax: $t\{r[1+i+w(1-t)]+w\}$

18. Retained after-tax business income (16.-17.): $(1+i)[i+w(1-t)]$

19. Capital stock at the end of the year $=$ revenue from sale of shares $(14 .+18):.(1+i)^{2}+(2+i) w(1-t)$

20. Basis of shares plus RRA for year 2 : $1+i+i(1+i)=(1+i)^{2}$

21. Capital gains tax $=\left(\frac{t^{t}-t}{1-t}\right) \times(19 .-20):.\left(\frac{t^{t}-t}{1-t}\right)(2+i) w(1-t)=\left(t^{l}-t\right)(2+i) w$

22. Net revenue from sale of shares (19.-21.): $(1+i)^{2}+(2+i) w\left(1-t^{l}\right)$

Comparing rows 9. and 22., we see that the entrepreneur ends up with the same net wealth under both organizational forms. The reason why the corporate organizational form does not imply any advantage from tax deferral is that when a shareholder retains and reinvests income in his company, the accumulated returns to this reinvested income will be taxed as labour income when the returns are ultimately distributed (since the retention does not add to the basis value of the shares). Thus the initial liquidity gain from postponement of the progressive labour income tax is offset by the fact that the postponed labour tax liability is effectively carried forward with a normal return, provided the reinvested income generates a normal return. 
In principle there is thus no tax discrimination between the self-employed and the owners of closely held companies. However, in practice many small enterprises may be subject to credit constraints and may therefore have to rely on retained earnings as the only realistic source of investment finance. In that case the entrepreneur's subjective discount rate would exceed the market interest rate, and he would prefer to be able to postpone the progressive surtax on labour income by retaining income in the firm. Under the tax regime described above the corporate form of organization would then be favoured. Furthermore, by organizing the firm as a company, the entrepreneur would be able to engage in income-averaging by appropriate timing of the realization of his shareholder income, thereby minimizing the impact of the progressive labour income tax by exploiting the rate-of-return allowance to the greatest possible extent. The self-employed will have no similar opportunity for income averaging.

To eliminate these sources of unequal tax treatment, one could allow the selfemployed to postpone the progressive surtax on their imputed labour income until the time the income is distributed from the firm to the owner, in line with current practice in countries like Denmark and Sweden. For tax accounting purposes, this requires that the income and wealth of the self-employed be split into a 'business' sphere and a 'private' sphere. However, this is administratively complex for this group of non-corporate taxpayers.

\section{IV.7. Taxation of income from public corporations}

In the large public corporations listed on the stock exchange there is normally a separation between managers and shareholders, so the dividends and capital gains earned by the latter should be categorized as capital income. Hence there is no need to split the income from listed companies.

For companies with access to the international stock market, the domestic personal tax rules for dividends and capital gains do not affect the cost of capital, as demonstrated by Boadway and Bruce (1992) and Fuest and Huber (2000), among others. Thus one could argue that there is really no need for provisions to alleviate the (domestic) double taxation of equity income from public corporations. However, as pointed out by Andersson et alia (1998) and Apel and Södersten (1999), domestic double taxation tends to discourage domestic ownership of shares in domestic companies. Such a bias in favour of foreign ownership may be undesirable from the viewpoint of policy makers. Moreover, since the crediting rules proposed for unlisted companies imply full relief 
for the double taxation of corporate equity income, it seems natural to alleviate the double taxation of income from listed corporations to avoid distorting companies' decisions to go public.

A simple way of alleviating the double taxation of dividends from public corporations would be to exempt such dividends from personal tax, provided dividends are paid out of taxed profits, and assuming again that the corporate income tax rate equals the personal tax rate on capital income. Just as unlisted corporations, all listed corporations would thus have to keep a taxed-profits account and to withhold tax on dividends paid out of untaxed profits.

For neutrality reasons double taxation of retained profits should also be avoided. Thus, when calculating the taxable capital gain on the realization of shares in listed companies, a deduction should be given for the shareholder's allotted share of the company's retained taxed profits. This would ensure that personal tax would be levied only on gains exceeding the profits that have already borne corporation tax, in line with current Norwegian tax practice. ${ }^{9}$

To facilitate corporate restructuring and to avoid double taxation of corporate taxpayers, dividends and capital gains on intercorporate shareholdings should be left free of tax. Thus tax should only be imposed at the time income is transferred from the corporate to the household sector, and only in so far as tax on the underlying profit has not already been paid at the corporate level.

\section{IV.8. The taxation of small companies in the Nordic countries}

Sections IV.3 through IV.6 outlined an 'ideal' dual income tax for closely held corporations, designed to achieve the maximum degree of tax neutrality. The present section briefly summarizes actual tax practices in the Nordic countries.

Finland, Norway and Sweden all have special tax rules for the owners of closely held companies. ${ }^{10}$ Until 2005, Finnish tax law required that the 'grossed-up' dividends from shares in non-listed companies exceeding an imputed return to the company's net assets be taxed as labour income, with a credit being granted for the underlying corporation tax. Dividends below the imputed return were effectively exempt from tax at the shareholder level, as a consequence of the

\footnotetext{
${ }^{9}$ From 2006 Norway will adopt new rules for the taxation of capital gains on shares. See section IV.9 below.

${ }^{10}$ Denmark does not have special tax rules for closely held companies. Instead, the country relies on a separate schedular progressive tax on dividends and capital gains on shares to ensure that the total corporate and personal tax burden on corporate equity income is roughly in line with the marginal tax rate on labour income.
} 
Finnish imputation system and the correspondence between the tax rates on corporate and capital income. Realized capital gains on shares were fully taxed as capital income. To reduce the tax incentive for owners of small companies to transform labour income into capital gains, Finland has thus accepted double taxation of retained corporate earnings. From 2005 Finland has abolished her imputation system. To maintain some alleviation of double taxation, only $70 \%$ of the dividend is included in the shareholder's capital income, and for unlisted companies only $70 \%$ of the dividend above the imputed return is included in taxable labour income. Moreover, dividends from nonquoted corporations are tax exempt up to a limit of 70,000 euros. For personal shareholders the rules for taxation of long-term capital gains have been slightly tightened.

Sweden imposes progressive labour income tax on dividends above an imputed return to the net assets of closely held companies. However, this is only done for dividends accruing to 'active' shareholders. Moreover, for all shares in non-quoted companies, dividends below an imputed return to the basis of the share are exempt from capital income tax, and unutilized rate-ofreturn allowances may be added to the basis of the share. Thus Sweden applies a mixture of the tax principles outlined in sections IV.2 and IV.3. Realized capital gains on shares are generally taxed as capital income, but half of the gain on shares realized by 'active' owners is taxed as labour income, up to a cap.

Since the introduction of the DIT in 1992, Norway has treated 'active' shareholders in much the same manner as the self-employed, applying a (complex) version of scheme described in section IV.2 above. However, because of the difficulties of distinguishing between active and passive shareholders, Norway is about to introduce (from 2006) a variant of the shareholder income tax described in section IV.3. The next section briefly compares the new Norwegian shareholder income tax to the tax scheme proposed in the present paper.

\section{IV.9. The Norwegian shareholder income tax versus the present proposal}

Under the new Norwegian rules for the taxation of income from shares, all Norwegian resident personal shareholders will become subject to tax on dividends and realized capital gains exceeding an imputed return to the stepped-up basis of their shares. Thus the tax will apply to holders of listed as well as unlisted shares. The 'excess' returns to shares will be taxed at the flat capital income tax rate which will come on top of the corporation tax on the underlying profits. Given the tax rate structure in Norway, the sum of the corporation tax and the capital income tax on the 'excess' returns to shares will correspond roughly to the top marginal tax rate on labour income, 
so the holders of shares in closely held companies will not be able to score any significant gain by transforming labour income into shareholder income. Hence the current income splitting rules for 'active' shareholders will be abolished. For the purpose of administering the new shareholder income tax, the Norwegian tax authorities will rely on a centralized, computerized register of all resident Norwegian personal shareholders which will keep track of the adjusted basis values of shares and of unutilized rate-of-return-allowances.

Since listed shares are traded much more frequently than unlisted shares, the Norwegian shareholder income tax is administratively more demanding than the tax scheme proposed in the present paper which will apply only to unlisted shares. Under the present proposal, the administration of the shareholder income tax will rely on information provided by unlisted companies to their shareholders and the tax authorities, so a centralized register of all resident shareholders will not be needed.

But perhaps the greatest advantage of the present proposal is that it offers more flexibility in the choice of tax rate structure and ensures that 'excess' returns on shares always get taxed at the 'correct' marginal rate. Under the new Norwegian tax scheme, the total marginal tax rate on shareholder income above the imputed return will be $\tau+t(1-\tau)$, where $\tau$ is the corporate income tax rate, and $t$ is the capital income tax rate levied on the 'excess' returns to shares. To ensure that active owners of closely held corporations cannot gain from transforming labour income into capital income (or vice versa), this total effective tax rate will have to be kept close to the top marginal tax rate on labour income. Clearly this will severely constrain the choice of tax rate structure. In particular, if future increases in capital mobility force a reduction in the tax rates on corporate income and capital income, the marginal tax rate on labour income will also have to come down. Hence a major advantage of the dual income tax - that it allows a separation between the marginal tax rates on capital and labour to account for differences in factor mobility - would seem to be lost.

The shareholder income tax proposed here avoids this problem by taxing shareholder income above the imputed return as labour income. On the other hand, because it applies to all personal shareholders, the new Norwegian shareholder income tax can be expected to raise more revenue, and it does have the advantage of treating listed and unlisted shares in an identical manner. 


\section{CONCLUSIONS}

The dual income tax combines a progressive tax schedule for labour income with a low flat tax rate on capital income and corporate income, levied on a broad base. A number of theoretical and practical arguments can be given in favour of such a tax system, but it does raise the technical problem that income from small enterprises must be split into a capital income component and a labour income component. This paper discussed alternative methods of taxing business income under a DIT, paying special attention to the challenge of taxing income from closely held corporations. We argued that the best way to meet this challenge is to tax an imputed normal return to shares in unlisted companies as capital income, and to impose labour income tax on above-normal returns. As demonstrated in the paper, such a tax scheme can be designed to be neutral towards the firm's investment and financing decisions and towards the decisions of shareholders to realize their shares.

The tax scheme proposed here has many similarities with the new Norwegian shareholder income tax described in Sørensen (2005), but it requires less administrative capacity and offers policy makers greater flexibility in the choice of tax rate structure. 


\section{REFERENCES}

Andersson, K., V. Kanniainen, J. Södersten and P.B. Sørensen (1998), Corporate tax policy in the Nordic countries, ch. 3 in P.B. Sørensen (ed.), Tax Policy in the Nordic Countries, Macmillan Press.

Apel, M. and J. Södersten (1999), Personal taxation and investment incentives in a small open economy, International Tax and Public Finance 6, 79-88.

Atkinson, A.B. and J. E. Stiglitz, The design of tax structure: Direct versus indirect taxation, Journal of Public Economics 6, 55-75

Auerbach, A.J. and D. Bradford (2004), Generalized cash flow taxation, Journal of Public Economics 88, 957-980.

Boadway, R. and N. Bruce (1992), Problems with integrating corporate and personal taxes in an open economy, Journal of Public Economics 48, 39-66.

Bovenberg, A.L. and R. Gordon (1996), Why is capital so immobile internationally? Possible explanation and implications for capital income taxation, American Economic Review $86,1057-1075$.

Chamley, C. (1986), Optimal taxation of capital income in general equilibrium with infinite lives, Econometrica 54, 607-22.

Chamley, C. (2001), Capital income taxation, wealth distribution and borrowing constraints, Journal of Public Economics 79, 55-69.

Cnossen, S. (2000), Taxing capital income in the Nordic countries: a model for the European Union?, in S. Cnossen (ed.), Taxing Capital Income in the European Union - Issues and Options for Reform, Oxford University Press.

Corlett, W. and D. Hague (1953), Complementarity and the excess burden of taxation, Review of Economic Studies 21, 21-30.

Eggert, W. and B. Genser (2005), Dual income taxation in EU member countries, CESifo DICE Report 3 (1), 41-47.

Fuest, C. and B. Huber (2000), Can corporate-personal tax integration survive in open economies? FinanzArchiv 57, 514-24.

Gordon, R. (1986), Taxation of investment and savings in a world economy, American Economic Review 76, 1086-1102. 
Hagen, K.P. and P.B. Sørensen (1998), Taxation of income from small businesses: Taxation principles and tax reforms in the Nordic countries, Ch. 2 in P.B. Sørensen (ed.), Tax Policy in the Nordic Countries, Macmillan Press.

Judd, K. (1985), Redistributive taxation in a simple perfect foresight model, Journal of Public Economics 28, 59-83.

Keuschnigg, C. and M. Dietz (2005), A growth-oriented dual income tax, CESifo Working Paper No. 1513.

Krusell, P., L. Ohanian, J.-V. Rios Rull, and G. Violante (2000), Capital-skill complementarity and inequality: A macroeconomic analysis, Econometrica 68, 1029-53.

Nielsen, S.B. and P.B. Sørensen (1997), On the optimality of the Nordic system of dual income taxation, Journal of Public Economics 63, 311-329.

Ordover, J. and E. Phelps (1979), The concept of optimal taxation in the overlapping generations model of capital and wealth, Journal of Public Economics 12, 1-26.

Salanié, B. (2003), The Economics of Taxation, MIT Press.

Sinn, H.-W. (2003), Ist Deutschland noch zu retten? Berlin: Econ Verlag.

Spengel, C. and W. Wiegard (2004), Dual income tax: A pragmatic reform alternative for Germany, CESifo DICE Report 2 (3), 15-22.

Sørensen, P.B. (1994), From the global income tax to the dual income tax: Recent tax reforms in the Nordic countries, International Tax and Public Finance 1, 57-80.

Sørensen, P.B. (ed.) (1998), Tax Policy in the Nordic Countries, Macmillan Press.

Sørensen, P.B. (2005), Neutral taxation of shareholder income, forthcoming in International Tax and Public Finance. 